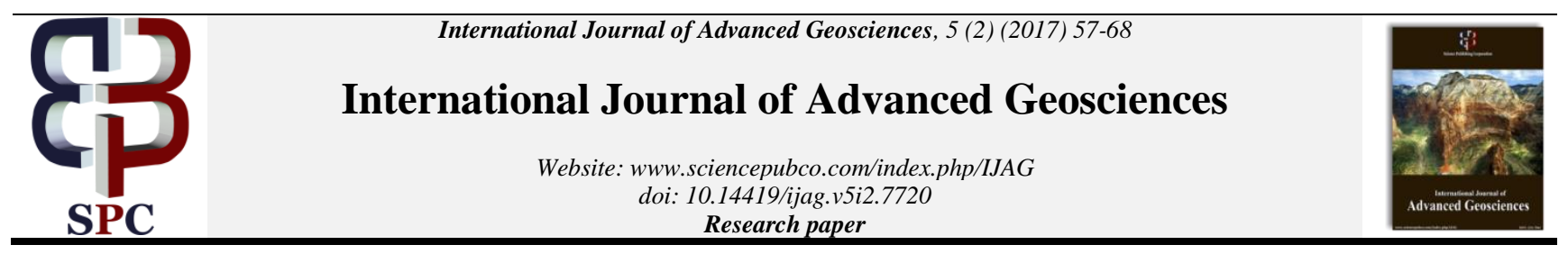

\title{
Depositional facies model and reservoir characterization of USANI field 1, Niger delta basin, Nigeria
}

\author{
G.O Aigbadon ${ }^{1 *}$, A.U Okoro ${ }^{2}$, C.O. Una ${ }^{2}$, A. Ocheli ${ }^{2}$ \\ ${ }^{1}$ Wesley University of Science and Technology, Ondo. Ondo State \\ ${ }^{2}$ Nnamdi Azikiwe University, Awka Anambra State \\ *Corresponding author E-mail: godwin.aigbadon@yahoo.com
}

\begin{abstract}
The 3-D depositional environment was built using seismic data. The depositional facies was used to locate channels with highly theif zones and distribution of various sedimentary facies. The integration core data and the gamma ray log trend from the wells within the studied interval with right boxcar/right bow-shape indicate muddy tidal flat to mixed tidal flat environments. The bell-shaped from the well logs with the core data indicate delta front with mouth bar, the blocky box- car trend from the well logs with the core data indicate tidal point bar with tidal channel fill. The integration of seismic to well log tie display a good tie in the wells across the field. The attribute map from velocity analysis revealed the presence of hydrocarbons in the identified sands (A, B, C, D1, D2, D4, D5). The major faults F1, F2, F3 and F4 with good sealing capacity are responsible for hydrocarbon accumulation in the field. Detailed petro physical analysis of well log data showed that the studied interval are characterized by sand-shale inter-beds. Eight reservoirs were mapped at depth intervals of $2886 \mathrm{~m}$ to $3533 \mathrm{~m}$ with their thicknesses ranging from $12 \mathrm{~m}$ to $407 \mathrm{~m}$. Also the Analysis of the petrophysical results showed that porosity of the reservoirs range from $14 \%$ to $28 \%$; permeability range from 245.70 md to $454.7 \mathrm{md}$; water saturation values from $21.65 \%$ to $54.50 \%$ and hydrocarbon saturation values from $45.50 \%$ to $78.50 \%$. The by-passed hydrocarbons were identified and estimated in low resistivity pay sands D1, D2 at depth of $2884 \mathrm{~m}-2940 \mathrm{~m}$, sand D5 at depth of $3114 \mathrm{~m}-3126 \mathrm{~m}$ respectively. The model serve as a basis for establishing facies model in the field.
\end{abstract}

Keywords: 3-D Depositional Environment; Depositional Facies; Reservoir Characterization.

\section{Introduction}

The Niger Delta Basin of Nigeria stands among the world's largest delta complexes. The sequence was described by Short and Stauble (1967) comprise from base to top; the Akata, Agbada and Benin Formation. The aspect of the petroleum geology of the basin are discuss in Merki, (1972), Weber and Daukoru, (1975), Evamy et. al. (1978). The reservoir rocks have been describe by LambertAikhionbare (1981). Detailed analysis from core and integrated seismic to well log approach is an important tool in 3-D geological modelling and reservoir characterization of oil and gas fields. The Niger Delta region have remained the major source of supply of hydrocarbon in Nigeria with less exploration and exploitation in the offshore. There is high rate of reduction of production with high rate of demand for its products for domestic, industrial applications and the increase of country's hydrocarbon reserve base to $40,000 \mathrm{bbls}$ of oils in 2018. Previous study was on reconnaissance scale and also lack the integration of core and well log data as well as the 3-D depositional model for effective characterization of the field. However little attention has been paid to the study field and detailed analysis has not been carryout too. This study focused on more detailed interpretation of environment of deposition, effective reservoir characterization, detailed evaluation of prospects and re- evaluation of the wells and position the present status of the Usani field, Niger Delta Basin, Nigeria.

\section{The aim and objectives}

The aim is to build 3-D geological model and characterize reservoir rocks in terms of quality. The specific objectives are to: Carryout detailed correlation of the sand bodies across the wells; establish relationship between lithofacies by integrating well log and core data and delineate the characteristics of the reservoir in the study field; generate synthetic seismograms from sonic and density well logs, tie synthetic seismograms to seismic data using synthetic seismograms and available check shot data; The use of seismic data to build 3-D geological model of the fluvial depositional environment.

\section{Field location}

Location of the study field Usani field is located at Oil Mining Lease (OML) 135, offshore Niger-Delta Basin of Nigeria Fig. (1). The Field covered a total area of $31 \mathrm{sqkm}$ offshore south western coast of Nigeria deep water. The base map for the study field is shown in Fig. (2) 


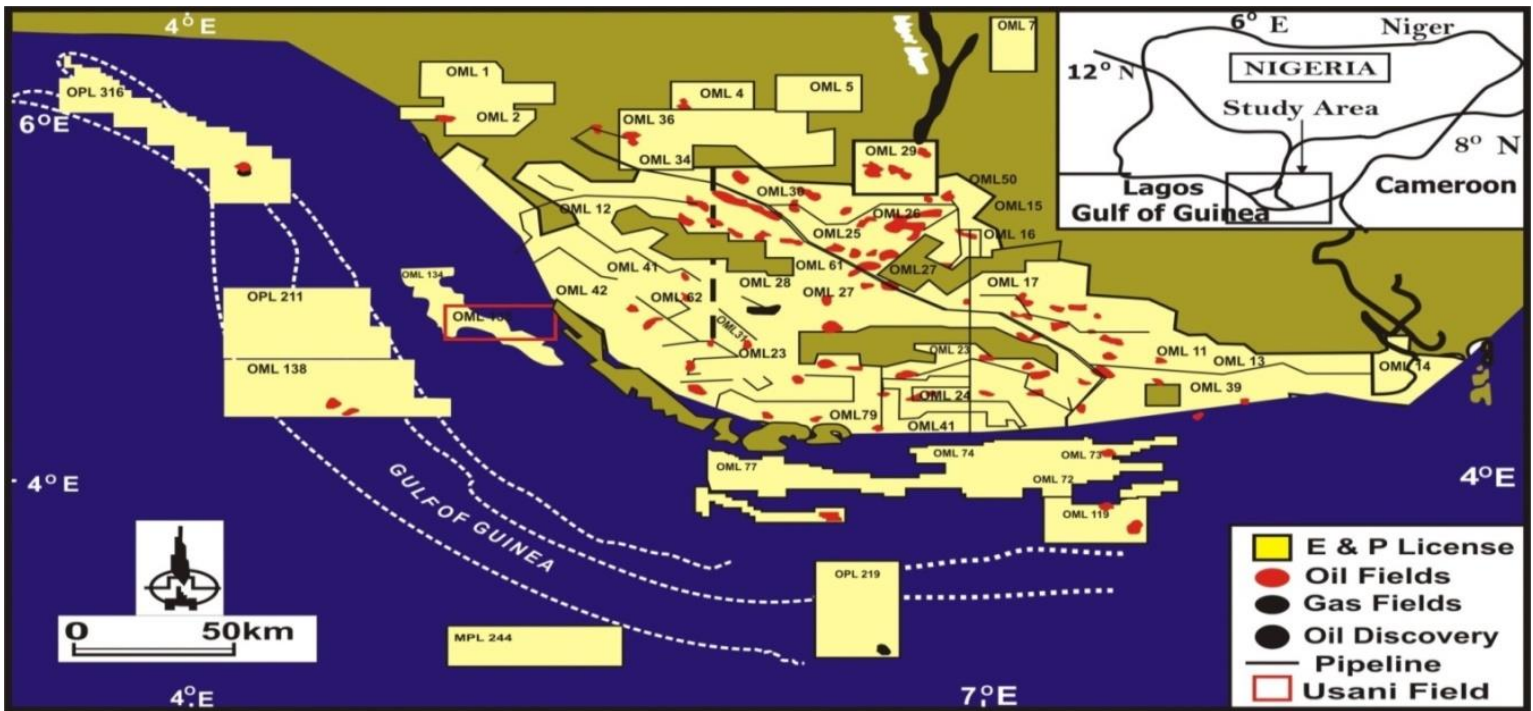

Fig. 1: Concession Map of Niger Delta Showing Study Area (Modified from Doust and Omatsola, 1990).

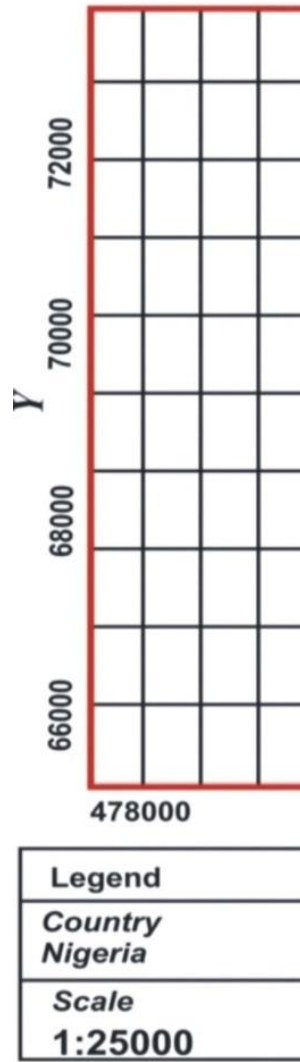

\section{Methodology}

The method of the study involved data acquisition for four well logs, core data, Base map, checks shot data and seismic data. The processing and interpretation of seismic data using petrel software, regional well correlation, qualitative analysis from Techlog environrnment, faults picked from seismic data along dip section, reservoirs identified on horizons by strong and continuous reflections, conversion of time and depth structure maps using check shot plots
(Fig.3), producing root mean square (R.M.S) amplitude maps from velocity model, seismic to well log tie using convolutional model Sheriff and Geldart (1999)). Producing 3-D geological model using petrel software 2010. Prospects identification and surface area extent determination using root mean square (R.M.S) amplitude values. Petrophysical evaluation using qualitative and quantitative techniques (After Archie, 1942, Wyllie and Rose 1958, Schlumberger, 2013, Asquith and Krygowski, (2004). 


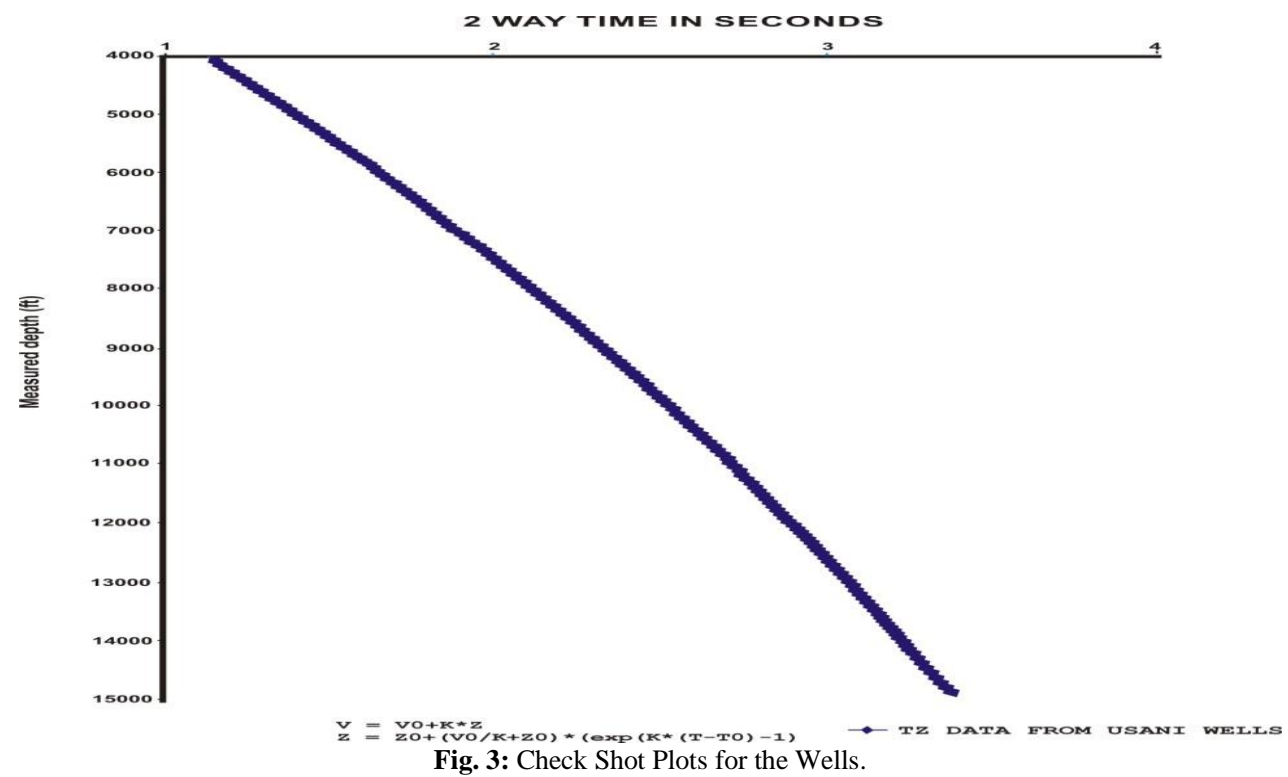

\section{Results and discussion}

Correlation in the Wells
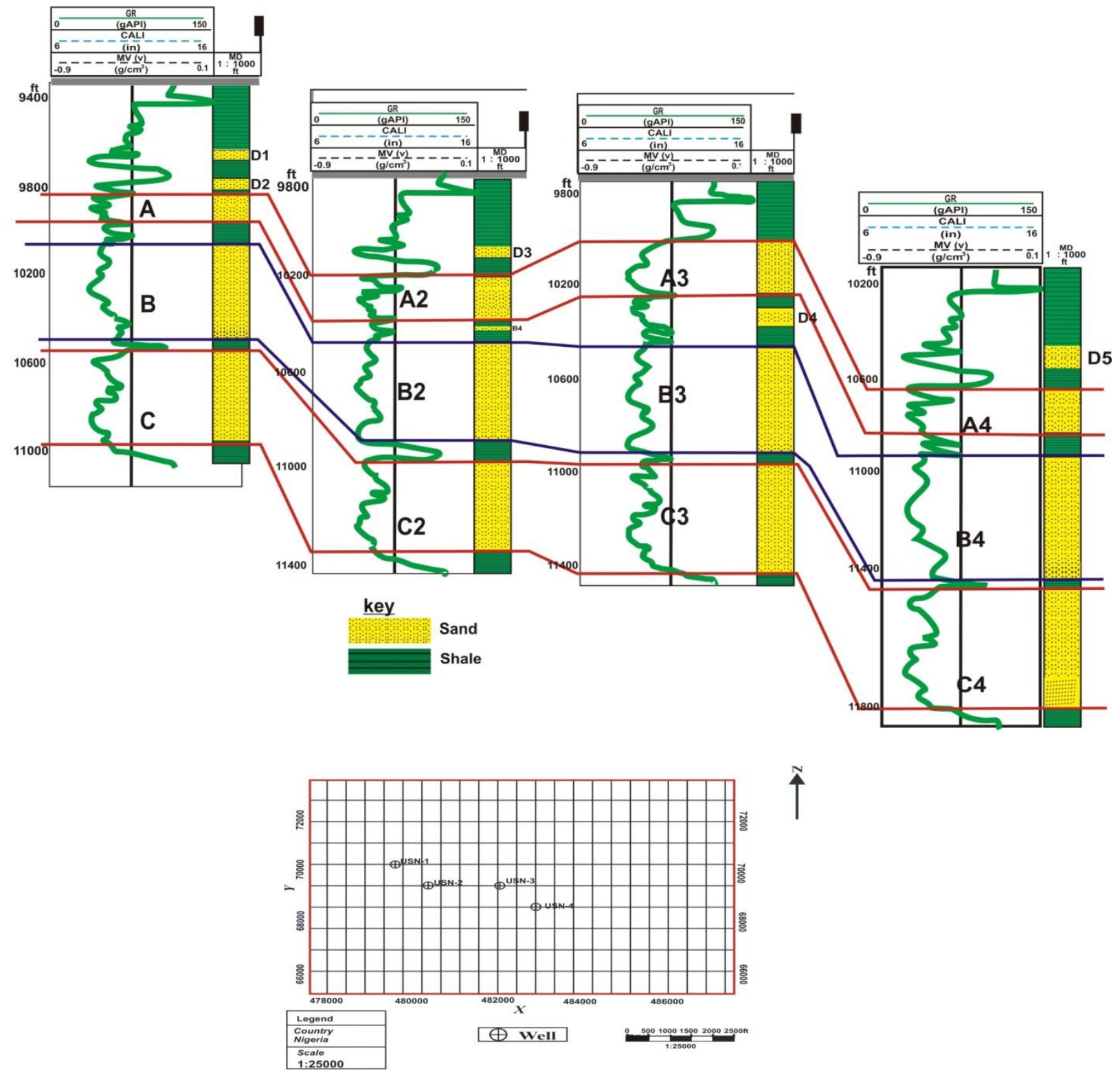

$\uparrow$

Fig. 4: Correlation in Well 1, 2, 3 and 4 in NW-SE Direction. 
The well correlation panel show the tops and bases of the reservoirs A, B, C, A2, B2, C2, A3, B3, C3, A4, B4, C4, in well 1-4 range from 2946-3532m respectively in Usani oil wells. The analysis of Gamma Ray (GR) and Spontaneous Potential (SP) logs shows that the overall lithology is an alternating sequence of sands and shales in Usani wells 1-4 (Fig. 4).

The correlation and analysis of the all the well section revealed that each of the sand units extends through the field and varies in thickness with some unit occurring at greater depth than their adjacent unit i.e possibly an evidence of faulting, where sand D1, D2, D3, D4, D5 exist as separates sand bodies. The shale layers were observed to increase with depth along with a corresponding decrease in sand layers. This pattern in the Niger Delta indicates transition from Benin to Agbada Formation (Amigun, 2013).

Root Mean Square Amplitude (RMS)

The amplitude map (Figs.5) shows area extent of the bright spots (Sweet spots) of various seismic attributes computed for the reservoirs. Having identified number of qualitatively bright spots, seismic amplitude was correlated with the well-log data of interest. The bright spots was caused by increased of hydrocarbon saturation across the top of the reservoirs. The observed outstandingly strong reflection (bright spots) is indicative of reservoir rocks, which may be due to the presence of hydrocarbons in the identified sands. Figure 5 shows the root mean square amplitude map of Horizons 1,2 $\& 3$ - the top of the reservoirs, amplitude levels are portrayed by the intensity of the colour, high amplitudes being represented by the range of reddish yellow colour and the lower amplitude by the range of dark blue areas. The high amplitude pattern observed around the well locations indicates bright spot which may be caused by velocity contrast between two layers (Fig.6).

Amplitude map (Fig.5) that was generated from velocity model for the mapped horizons was to compliment the structural interpretation. The distinct zones of anomalous amplitude coincide with structural high already delineated and which also coincided with the regions where wells have been drilled (Fig.5). Since the amplitude map correlates with the structurally high locations and bright spots from seismic attributes analysis, the distribution of low amplitudes and high amplitudes would be a useful guide in development of the well drilling of the Usani oil wells and future well drilling and development.

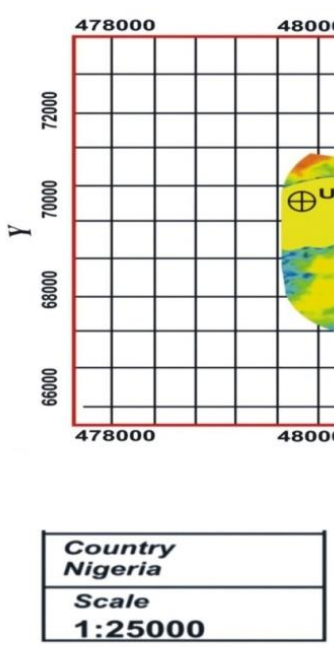

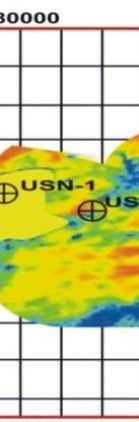

10000

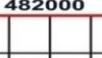

484000
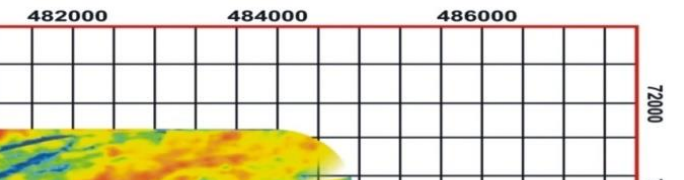
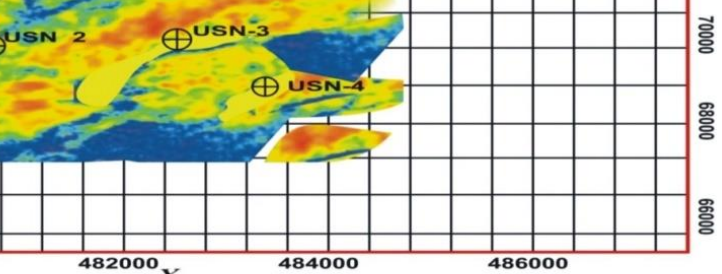

Legend
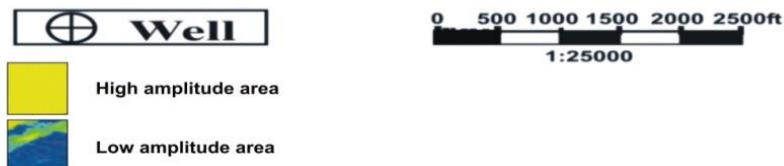

Fig. 5: RMS Amplitude Map of Mapped Area of Interest.

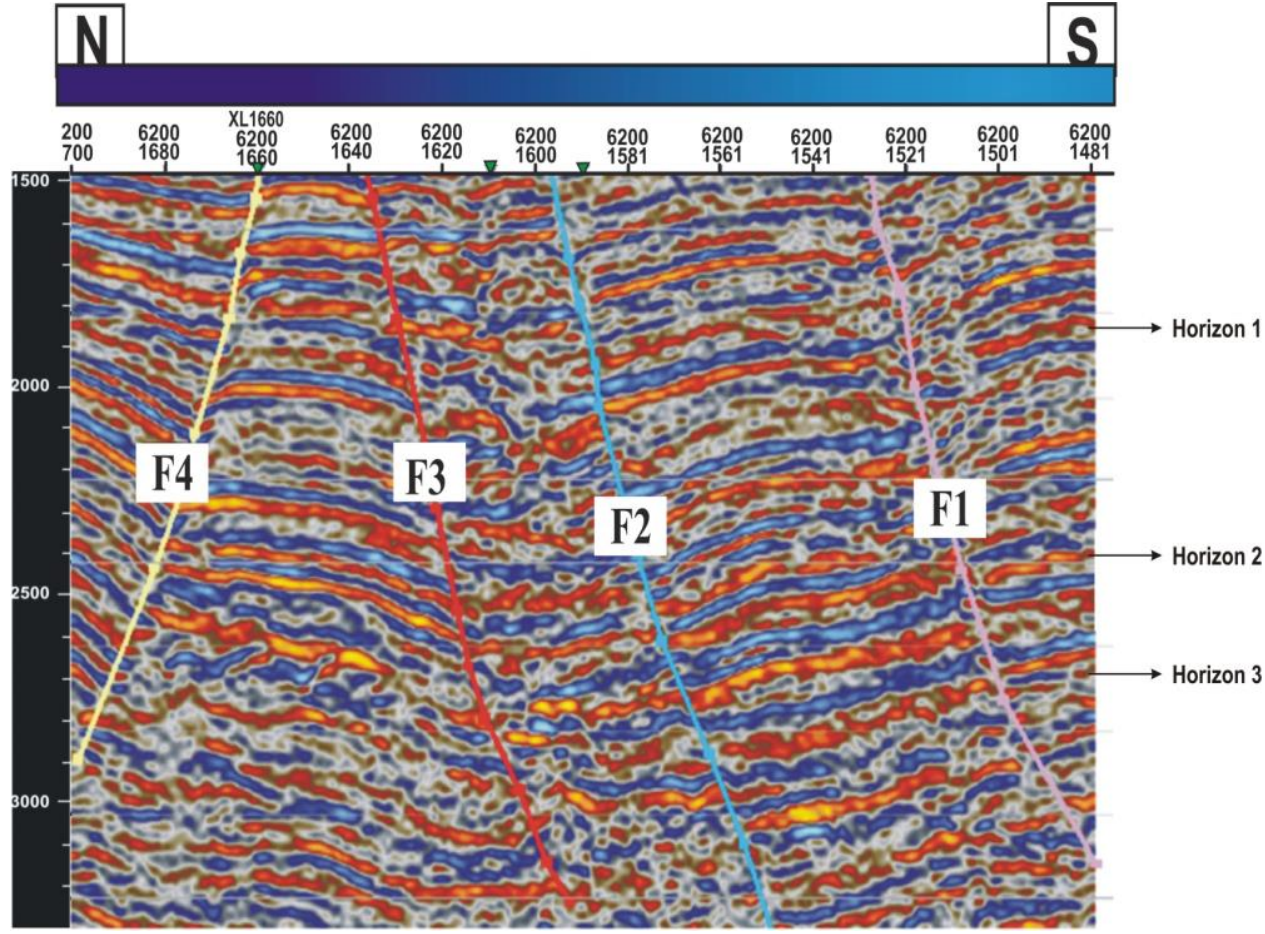

Fig. 6: Typical Seismic Section (Inline 5822) Showing Faults Patterns. 


\section{Seismic attribute interpretation}

The in-line section shows reflected events at time window of $1.500 \mathrm{msec}-3.300 \mathrm{msec}$ at interval of T700 and T1400 offsets, with well locations situated between T1160 and T1220 in the in-line seismic sections.

From $2700 \mathrm{~ms}-3000 \mathrm{~ms}$ show low amplitude facies, low continuity reflection, highly chaotic- indicating shales and fine particles (Akata Formation). The seismic reflection pattern for the unit with time slice $3.00 \mathrm{msecs}$ and above displays hummocky to chaotic configuration, with weak - moderate reflection strength and low amplitude. The reflection continuity range from poor to very poor, the unit have been formed by gravitational slumping as result of overloading of massive sand deposit on shale. The transport indicate a high energy basin slope on a lower energy basin slope and deep water environment (Fig.6).

From $2200 \mathrm{~ms}-2600 \mathrm{~ms}$ display high continuity reflection, high- medium amplitude facies and continous alternation of sand and shale, indicating the Agbada Formation. This unit is interpreted as thick massive sand bodies with inter-bedded shales deposited in a lowmedium energy deltaic front. The Well-logged intervals fall within these Units and these falls within the time slice of about $2250 \mathrm{msec}$ $-2650 \mathrm{msec}$. These units are the reservoirs of the wells in the field (Fig. 6).

From $1500 \mathrm{~ms}-2000 \mathrm{~ms}$ show poor continuity reflection, low amplitude facies with discontinous beds- indicating unconsolidated massive sand bodies (Benin Formation). Unit is characterized by subparallel reflection pattern, which can be infer as Fair to moderate continuity and low-medium amplitude. This Unit also depicts fair to moderate reflection strength with a down-lapping pattern and located at time window interval of about $1500 \mathrm{msec}$ to $2000 \mathrm{msec}$ (Fig.6).

\section{Faults interpretation}

The major faults are F1, F2, F3 and F4 with good sealing potential act as the traps of the reservoirs at the centre. The whole of the wells section revealed that each of the sand units extends through the field and varies in thickness with some unit occurring at greater depth than their adjacent unit i.e possibly an evidence of faulting. The shale layers were observed to increase with depth along with a corresponding decrease in sand layers. This pattern in the Niger Delta indicates transition from Benin to Agbada Formation (Amigun, 2013).

\section{Time and depth structure maps}

Figures 7-8 show respectively the time and depth structure maps generated from 3-D structural interpretation. The time structure map (Fig.7) shows the dominant trap in the Field. This principal structure responsible for hydrocarbon entrapment in the field is a structural high located at the center of the field which probably corresponded to the crest of the roll over structure observed on the seismic section. This was observed as fault assisted closures on the time structure maps of each horizon. Structural highs are observed in the northeast and in the center of the field while structural lows are observed in the southwest. Using the information on this map, shows that the growth fault F1, F2, F3, F4, F5 act as good traps for the hydrocarbon accumulations in well 1,2, 3 and 4 at the center of the field (Central channel belt).

The depth structure map generated (Fig.8) revealed that for horizons one and two, the depth to the top of hydrocarbon ranges between $9200 \mathrm{ft}-11800 \mathrm{ft}(2771-3554 \mathrm{~m})$ at 2500-2800ms in wells 1,2 , 3 and 4 at the center of the field.

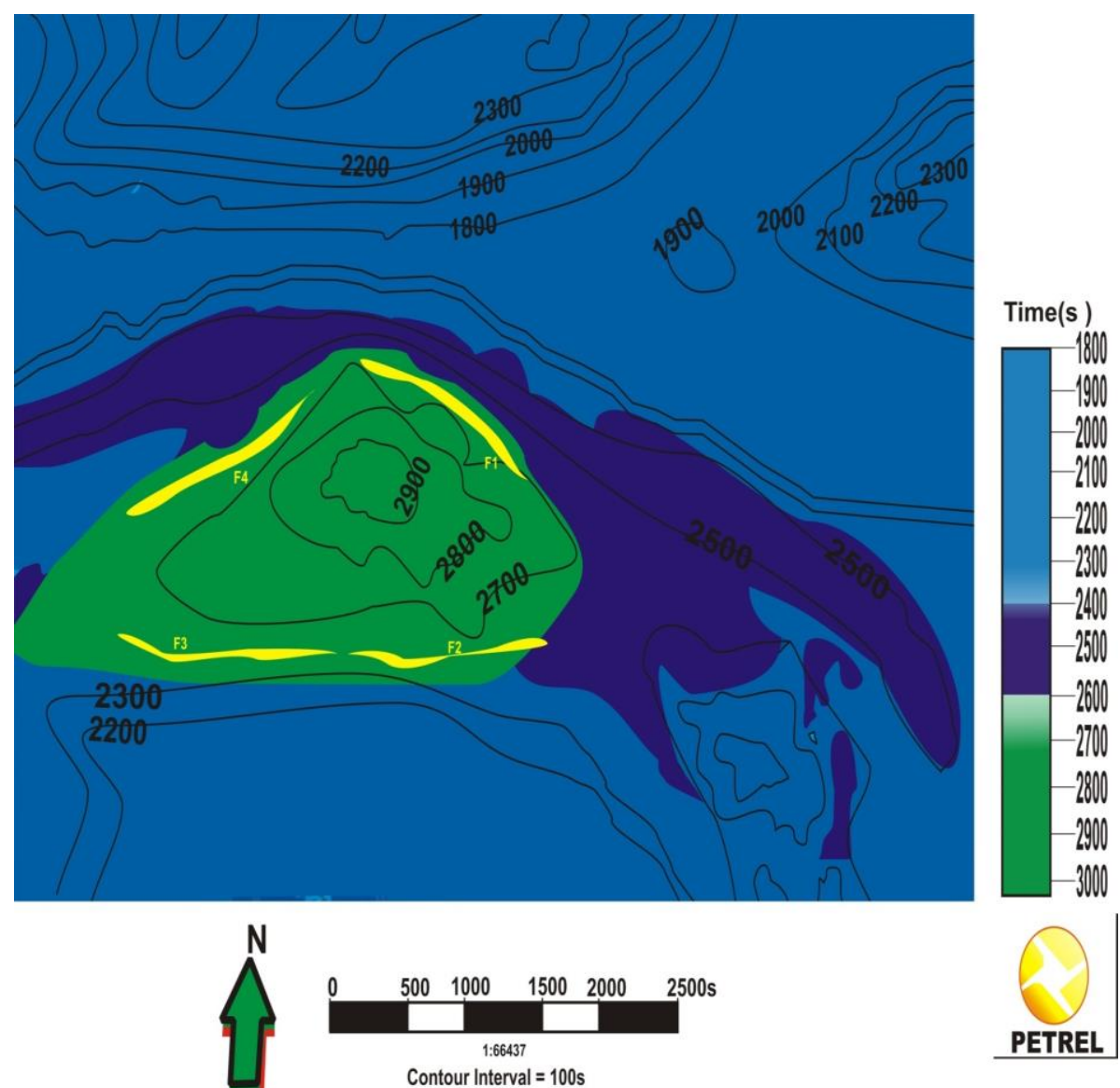

Fig. 7: Time Structure Map for the Mapped Horizons (H1 \& H2). 


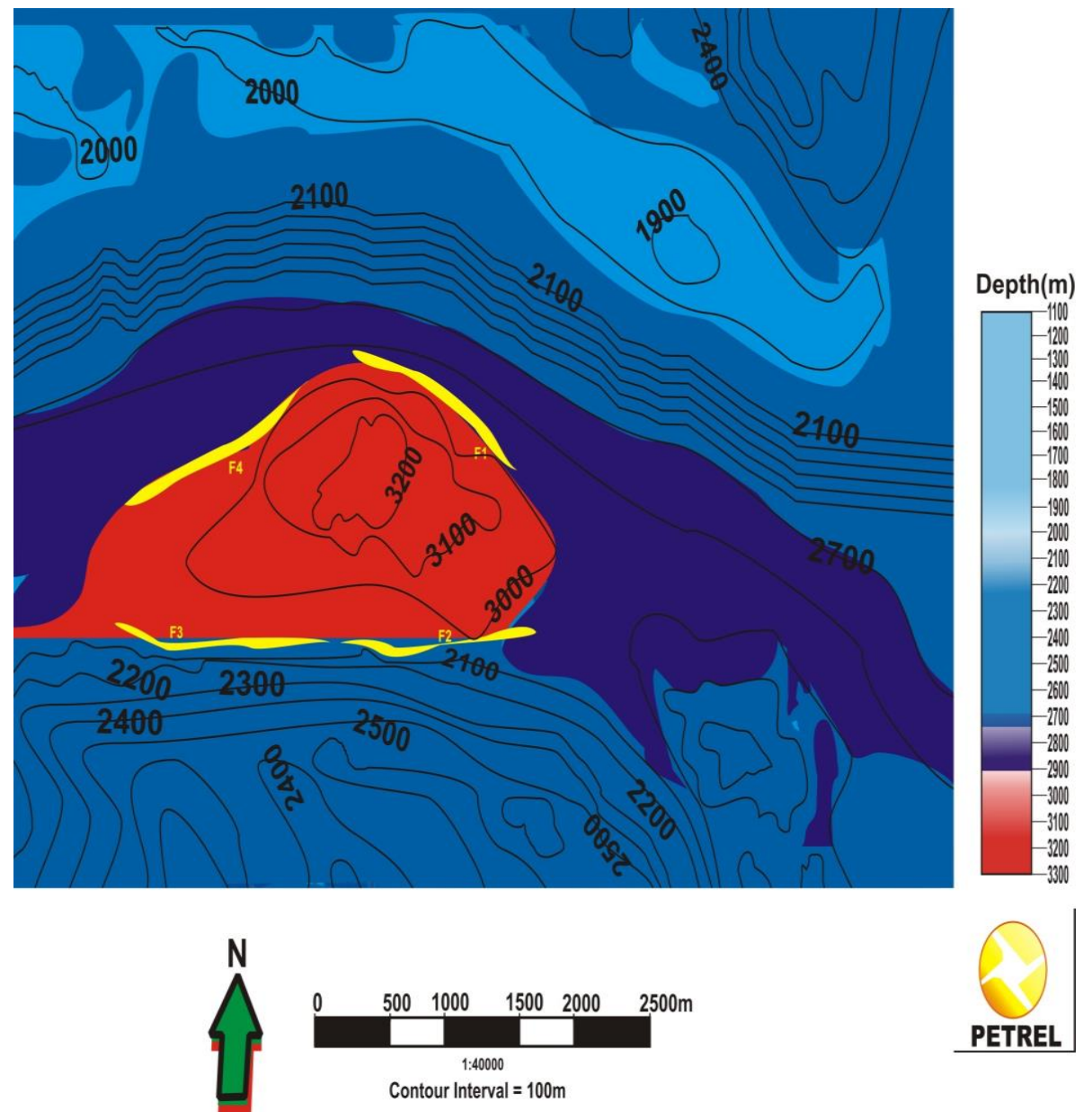

Fig. 8: Depth Structure Map for the Mapped Horizons (H1\& H2).

\section{Seismic to well log tie}

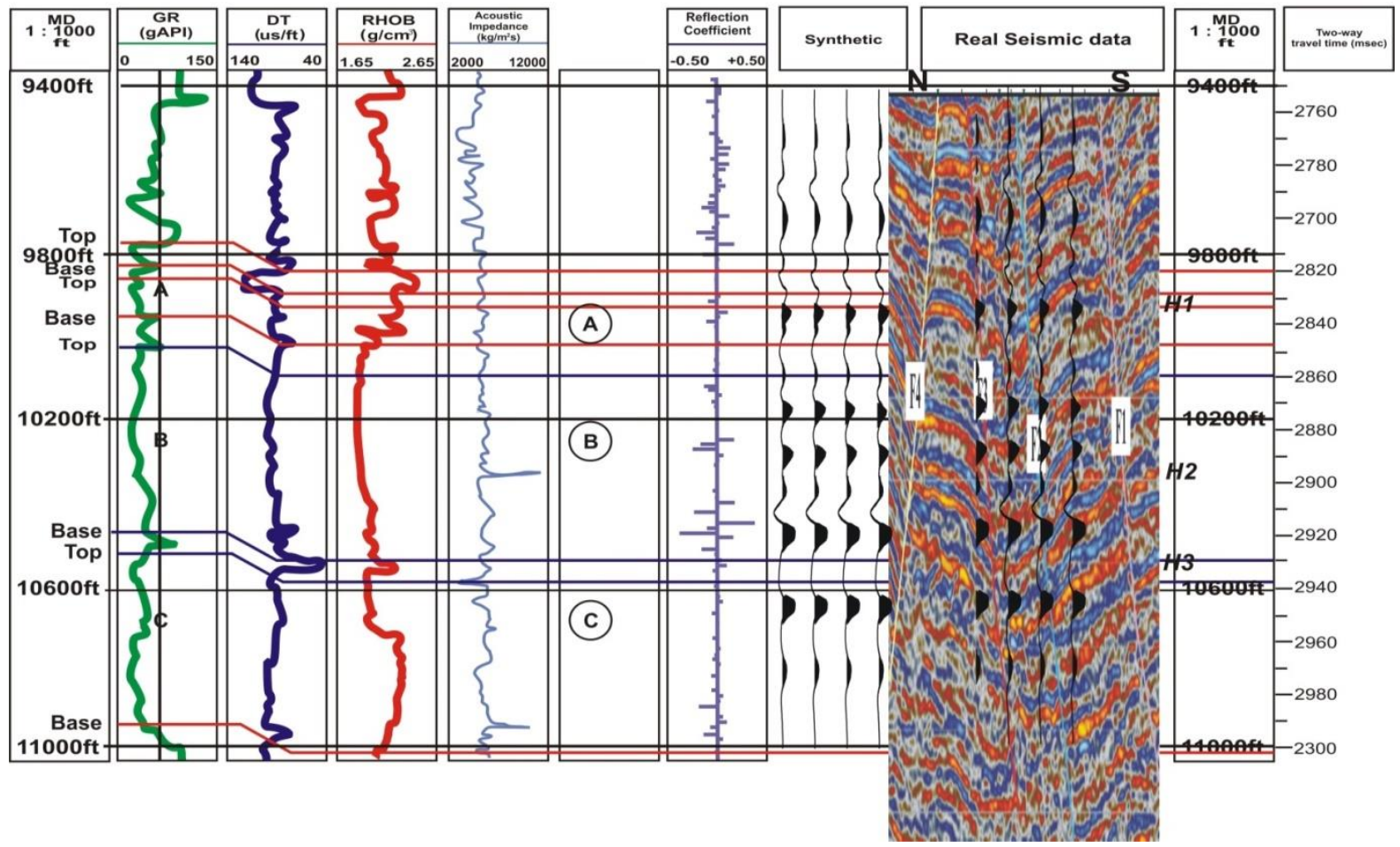

Fig: 9: Synthetic Seismogram and Well to Seismic Tie in Well 1. 
The seismic to well log tie show a good tie and a perfect match was established between the synthetic seismogram wave form and the seismic data, revealing that high -amplitude reflection events corresponds to the reservoirs areas (A, B, C, A2, B2, C2) while low- amplitudes reflection events correspond non- reservoirs (shale units). The seismic event also, correspond to the top of reservoirs picked at horizons 1 and 2 using well tie as a guide to recognized the event Figs (9-10).

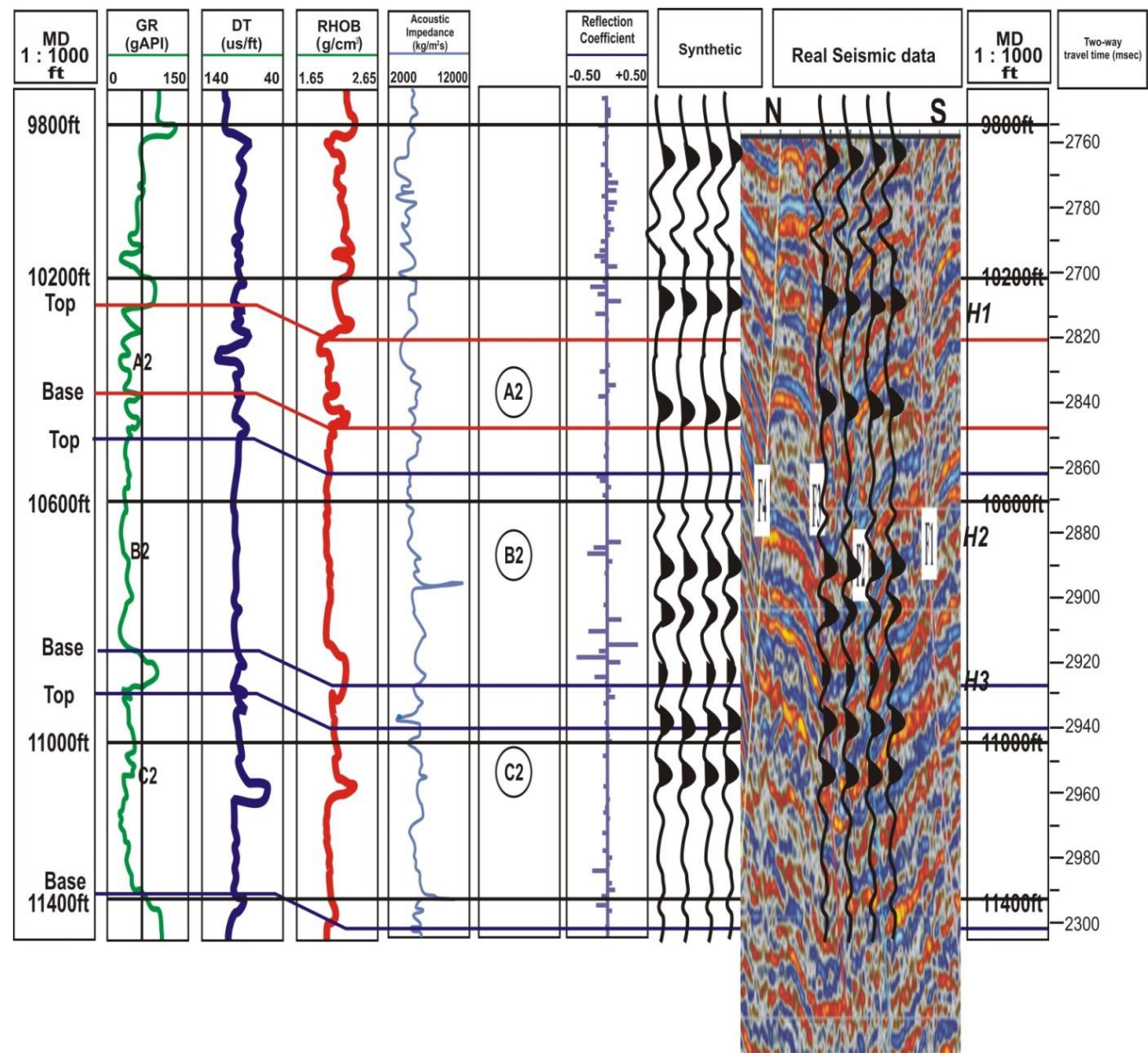

Fig. 10: Synthetic Seismogram and Well to Seismic Tie in Well 2.

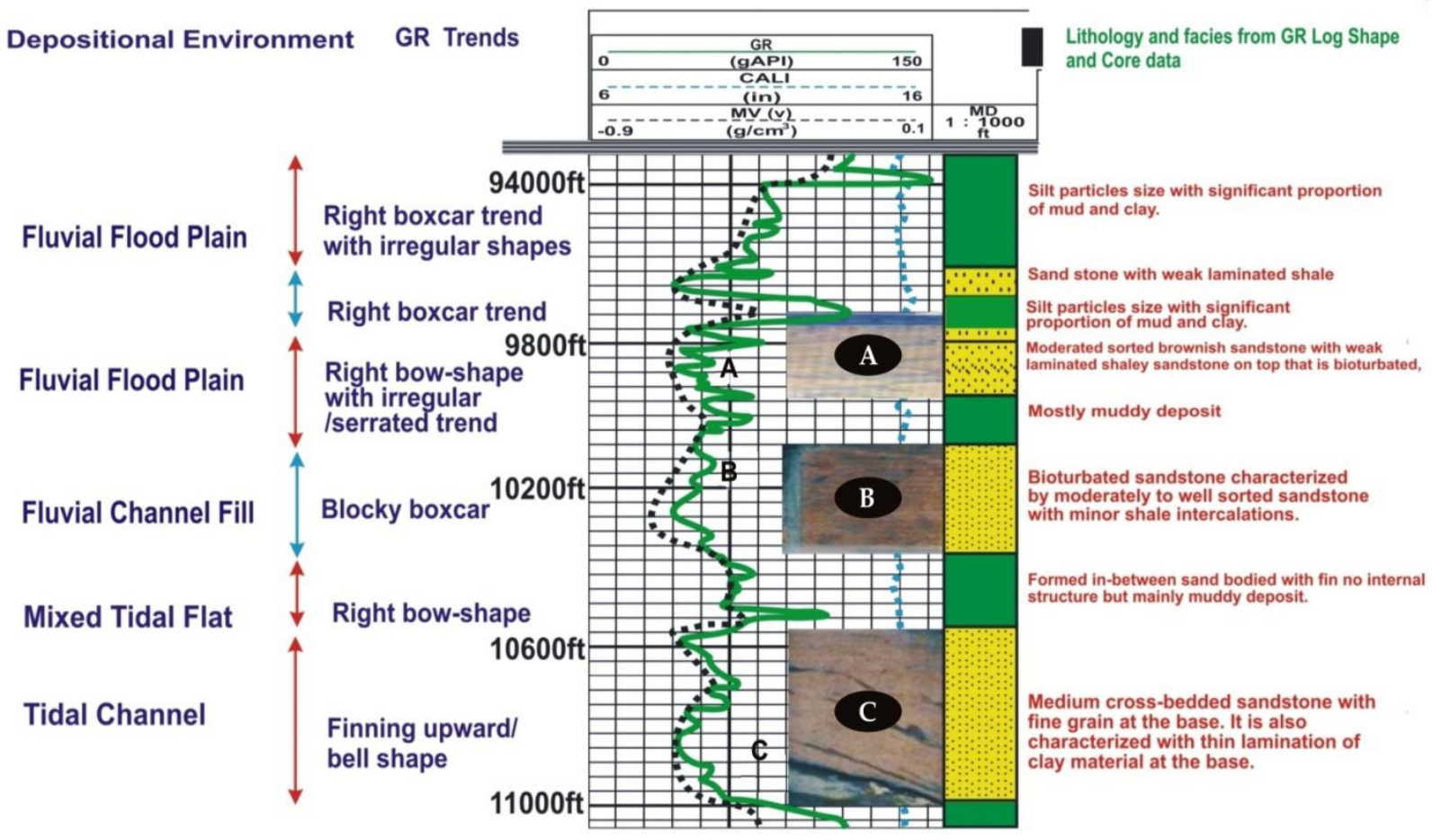

Fig. 11: Depositional Environment in Well 1. 


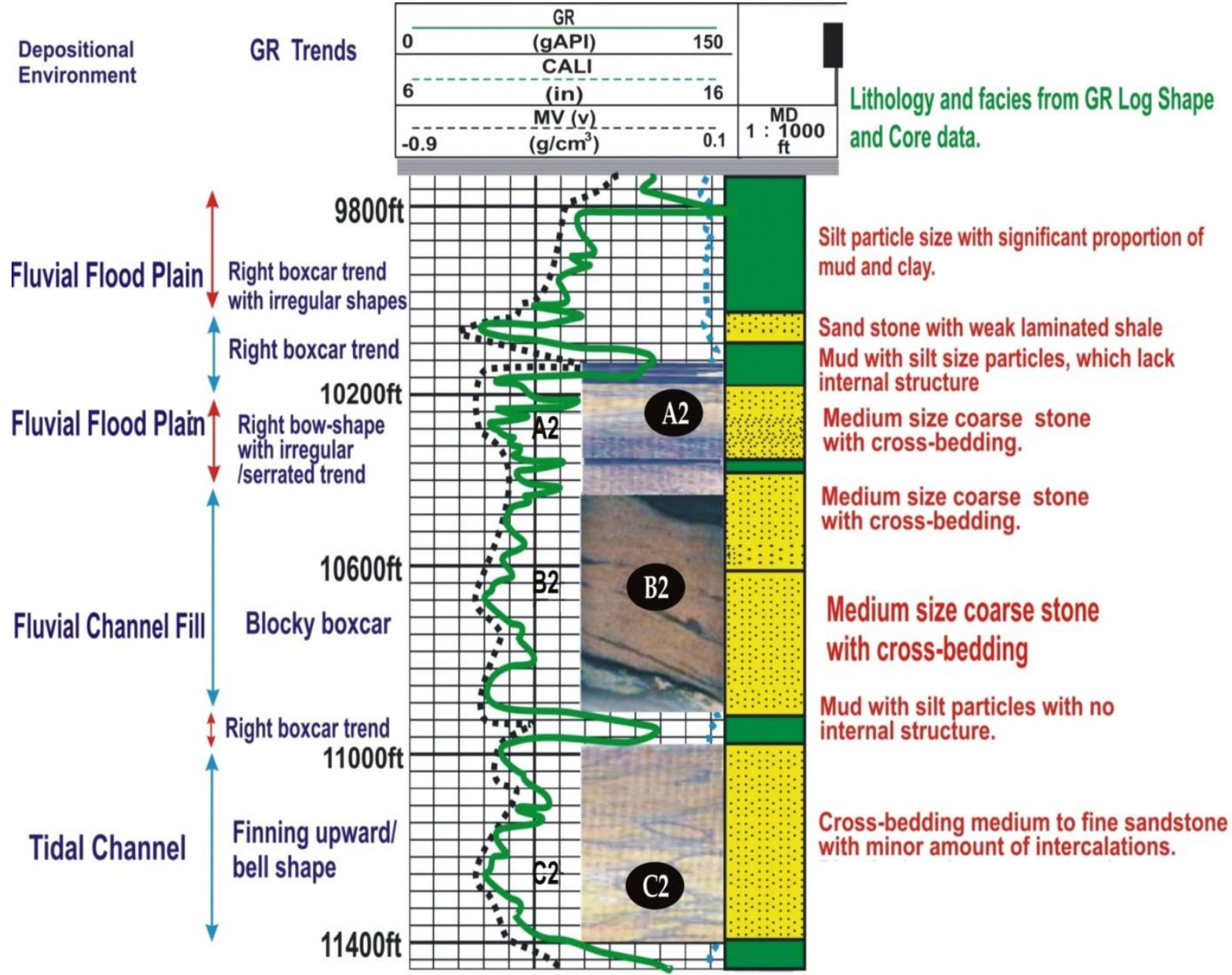

Fig. 12: Depositional Environment in Well 2.

\section{Log facies and depositional environment interpretation}

Gamma Ray log shapes were used to define the log facies and depositional environments in the study. The analysis of the Gamma Ray logs indicate that the log motif fall mostly into three categories namely: right box car trend with Irregular shapes or right bow shape, blocky and bell shaped.

The right box car trend with Irregular shapes or right bow shape, (Figs.13) according to Cant (1992), the trend has no character, representing aggradation of shales and silts. The irregular shape of the Gamma Ray is prominent in well 1 at depth $9320 \mathrm{ft}-94580 \mathrm{ft}$ (2807$2849 \mathrm{~m}$ ). This irregular Gamma Ray shape and core data is characterized by blackets of clays and fine silts suspended deposits with high lateral continuity and low lithologic variation at well 1 . According to Cant (1992) the deposition is entirely from suspension, parallel laminae, are by far the most common primary structure. These indicate muddy tidal - flat to mixed tidal-flat environments.

\section{Cylinderical (blocky) shape log pattern of some sand units in USANi field}

The blocky box car shaped Gamma Ray logs which occur in the study area are serrated. This motif is dorminant in the reservoir units A, B, C in well 1, A2, B2, B2 in well 2, (Fig.13) according to Cant (1992), the blocky car - shaped Gamma Ray log indicate a tidal channel environments. Emery and Myers (1996), blocky box car log pattern with significant thickness indicate trangressive and regressive sand. The sands are found in C, at depth $10720 \mathrm{ft}-10760 \mathrm{ft}$ (3229-3241m). The turbidite sands associated with the wells belong to upper Akata Formation of the Niger Delta which is composed of reservoir sands in the deeper water Cant (1992). The blocky shaped log pattern imply constant energy level during continued deposition.

The reservoir units of B, B2, indicate a distributary channel fills which are made up of coarse sands with good porosity as evident from sonic logs and core data with good sorting and permeability. These sands form a good reservoirs (Fig.11-12, 13).

\section{Bell shaped sucessssions}

The Gamma Ray log motif in well 1 from 10800ft-11000ft (3253$3313 \mathrm{~m})$ in well 2 from depth $11200 \mathrm{ft}-11400 \mathrm{ft}(3373-3343)$ is serrated and funnel shaped in the wells.

The funnel shape is a coarsening upward sequence. This log pattern is usually interpreted to indicate depositional well sorted upward sediment and presences of point bars at depth $9600 \mathrm{ft}(2892 \mathrm{~m})$, $9820 \mathrm{ft}(2958 \mathrm{~m}), 10600 \mathrm{ft}(3193 \mathrm{~m})$ in well 1 . The over bank deposit is a deposits of deltaic sediments formed after flooding of the bank which lead to fan- shaped sand deposits on the delta plain. Gluyas and Swarbrick (2004) classified the crevasse under the deltaic depositional system. The point bar and sand deposits is observed therefore of deltaic/fluvial settings and this characteristics of the Agbada Formation where channels serve as main reservoirs (Bush 1975, Cant, 1992), see Figs. 13. 


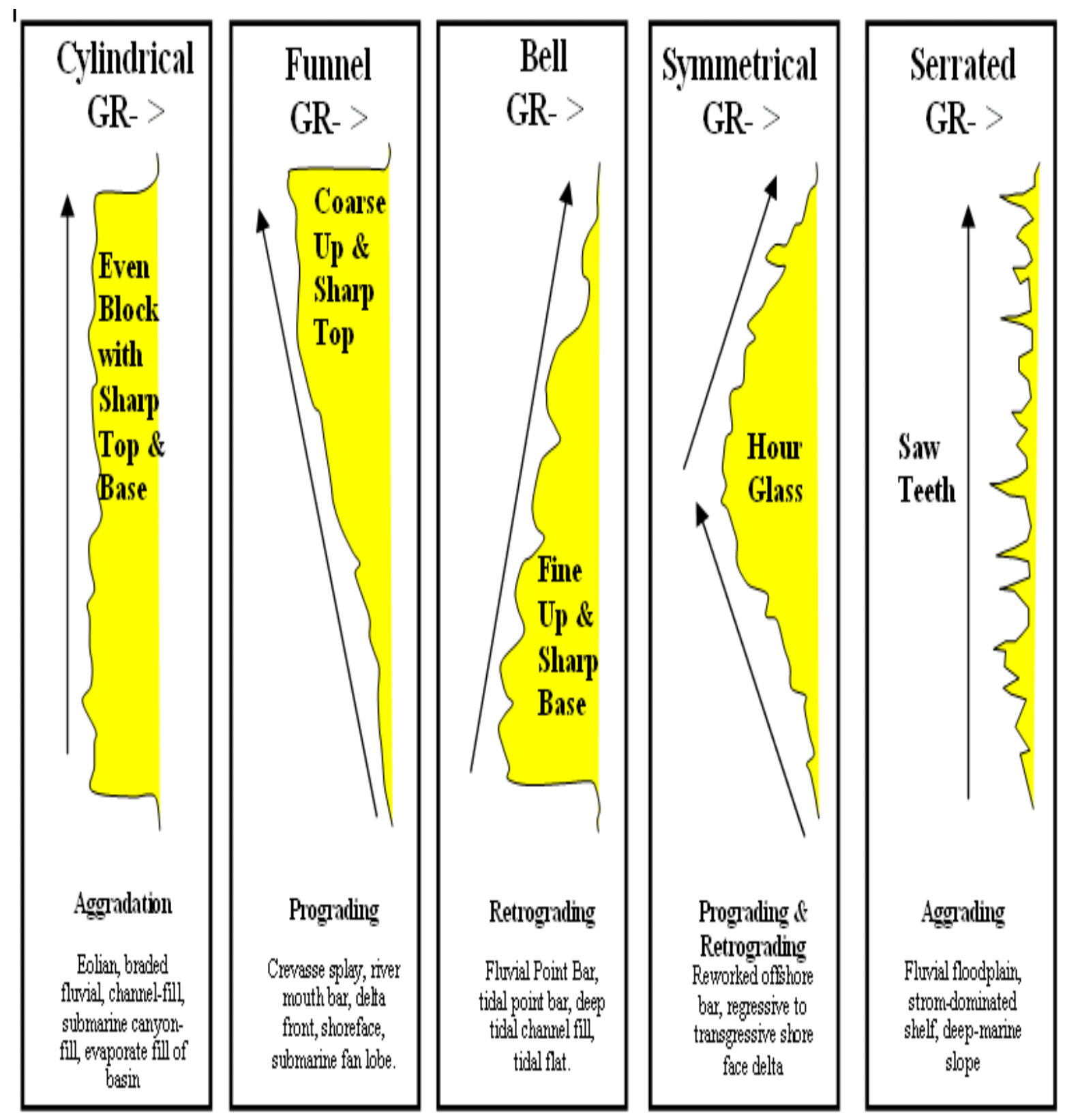

Fig. 13: Direct Correlation Between Facies and A Variety of Other Log Shapes Relating to Sedimentological Relationship by Cant (1992).

Table 1 Parameters for Creating Channels of the Study Area.

Table 1: Parameters for Building the 3-D Depositional Model of the Study Field

\begin{tabular}{llc}
\multicolumn{2}{c}{ Table 1: Parameters for Building the 3-D Depositional Model of the Study Field } \\
\hline S/N & Parameters & Values \\
\hline 1 & Sinuosity & 1.23 \\
2 & Length & $32,000 \mathrm{~m}$ \\
3 & Distance & $18,300 \mathrm{~m}$ \\
4 & Depth & $200 \mathrm{~m}$ \\
5 & Amplitude & $1500 \mathrm{~m}$ \\
6 & Wavelength & $7800 \mathrm{~m}$ \\
7 & Average seismic velocity & $2270 \mathrm{~m} / \mathrm{s}$ \\
\hline
\end{tabular}




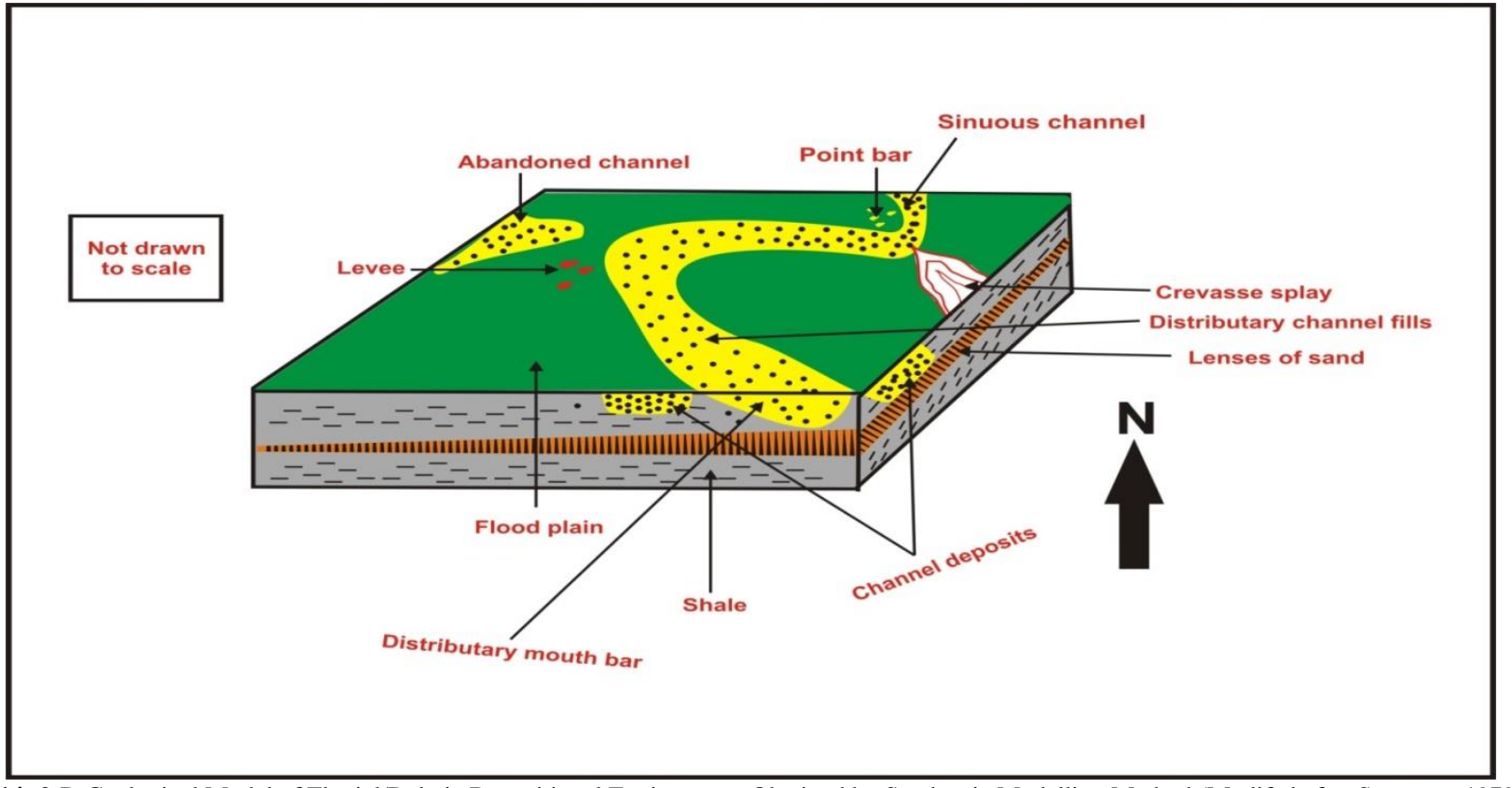

Fig. 14: 3-D Geological Model of Fluvial/Deltaic Depositional Environment Obtained by Stochastic Modelling Method (Modifed after Swanson, 1979).

From the 3-D geological model of the fluvial depositional environment (Fig.14) obtained from the stochastic model show that the depositional facies are mainly of sands, shale, flood plain (mixed deposits - mainly of mud and silts), leeve sand, crevasse splay, point bar deposits. This is a typical fluvial / deltaic facies. The wells are located in the channels, the net to gross ratio, net pay sand and porosities and permeability values are good indicating high quality sands in the reservoirs.

\section{Petrophysical analysis results}

The net to gross sand range from $0.48-0.81$, net pay sands are high enough for hydrocarbon production because of its sand quality (Table 2). Oil- water Contact (OWC) was detected at depth 3006$3018 \mathrm{~m}$ within reservoir D3 in the field and see table 2 for details. The geological net pay sands in Fig. (14.) Show the thicknesses and producing area of the reservoirs from the 3-D geological model. The by passed hydrocarbon in low resistivity pay zones D1, D2 at depth 2886-2940m have resistivity values of 0.6- $2.0 \mathrm{ohms}$, reservoir D3 at depth $3006-3018 \mathrm{~m}$ have resistivity value of $0.8-2.0$ ohms and reservoir D5 at depth $3114-3126 \mathrm{~m}$ have low resistivity values of 2-4 ohms (table 2).
Effective Porosity and Core Porosity values in the Wells The effective porosity values range from $14 \%-28 \%$ are good enough to support hydrocarbon production in the wells.

\section{Permeability range across the field}

The permeability values range from $245.50 \mathrm{md}-454.70 \mathrm{md}$ and this falls within the range of $50-1000 \mathrm{md}$ by Etu-efeotor (1997). The calculated permeability values are high enough to support movability of hydrocarbon in reservoirs to the wells.

\section{Shale volume in the wells}

The shale contents are from 0.033- 0.048 , and is not high enough to hinder production of hydrocarbon from reservoirs A, B, C, in the wells. The estimated shale volume at the bypassed reservoirs (D1, D2, D3, D4, D5) ranges 0.038- 0.093 in the wells and such will support production in the field. Though the water saturation values are high in sands D1, D2.

Table 2: Petrophysical Results for Usani Wells

\begin{tabular}{|c|c|c|c|c|c|c|c|c|c|c|c|c|}
\hline Reservoirs & $\begin{array}{l}\text { Depth } \\
\text { (ft) }\end{array}$ & $\begin{array}{l}\text { Depth } \\
\text { (m) }\end{array}$ & $\begin{array}{l}\text { Gross } \\
\text { Sand }\end{array}$ & $\begin{array}{l}\text { Net Pay } \\
\text { Sand (h) } \\
(\mathrm{m})\end{array}$ & $\begin{array}{l}\text { Shale } \\
\text { Vol. } \\
\left(\mathrm{V}_{\mathrm{sh}}\right)\end{array}$ & $\begin{array}{l}\text { Net to } \\
\text { Gross } \\
\text { (NTG) }\end{array}$ & Contact & $\begin{array}{l}\varnothing \\
(\%)\end{array}$ & $\begin{array}{l}\mathrm{K} \\
\text { (md) }\end{array}$ & $\begin{array}{l}S_{\text {wa }} \\
(\%)\end{array}$ & $S_{h}(\%)$ & Remarks \\
\hline D1 & $9640-9680$ & 2884-2896 & 12.00 & 6.00 & 0.045 & 0.50 & & 0.14 & 245.70 & 0.461 & 0.539 & Gas \\
\hline D2 & $9780-9820$ & $2928-2940$ & 12.00 & 5.40 & 0.048 & 0.55 & & 0.14 & 245.70 & 0.455 & 0.545 & Gas \\
\hline A & $9840-10600$ & 2946-3174 & 228.00 & 161.60 & 0.033 & 0.81 & GWC & 0.28 & 454.70 & 0.201 & 0.899 & Gas \\
\hline D3 & 1004-1008 & $3006-3018$ & 12.00 & 7.00 & 0.093 & 0.43 & OWC & 0.16 & 255.00 & 0.518 & 0.482 & Water \\
\hline D4 & 1024-10360 & $3065-3102$ & 36.00 & 24.00 & 0.083 & 0.66 & & 0.20 & 3005.00 & 0.470 & 0.530 & Oil \\
\hline B & $10400-11400$ & $3006-3413$ & 407.00 & 310.00 & 0.035 & 0.80 & & 0.25 & 423.70 & 0.195 & 0.805 & Oil \\
\hline D5 & $10400-10440$ & $3114-3126$ & 12.00 & 5.400 & 0.048 & 0.45 & & 0.18 & 285.00 & 0.330 & 0.670 & Oil \\
\hline $\mathrm{C}$ & $10560-11800$ & $3162-3533$ & 371.00 & 286.00 & 0.038 & 0.77 & & 0.22 & 350.00 & 0.200 & 0.800 & Oil \\
\hline
\end{tabular}




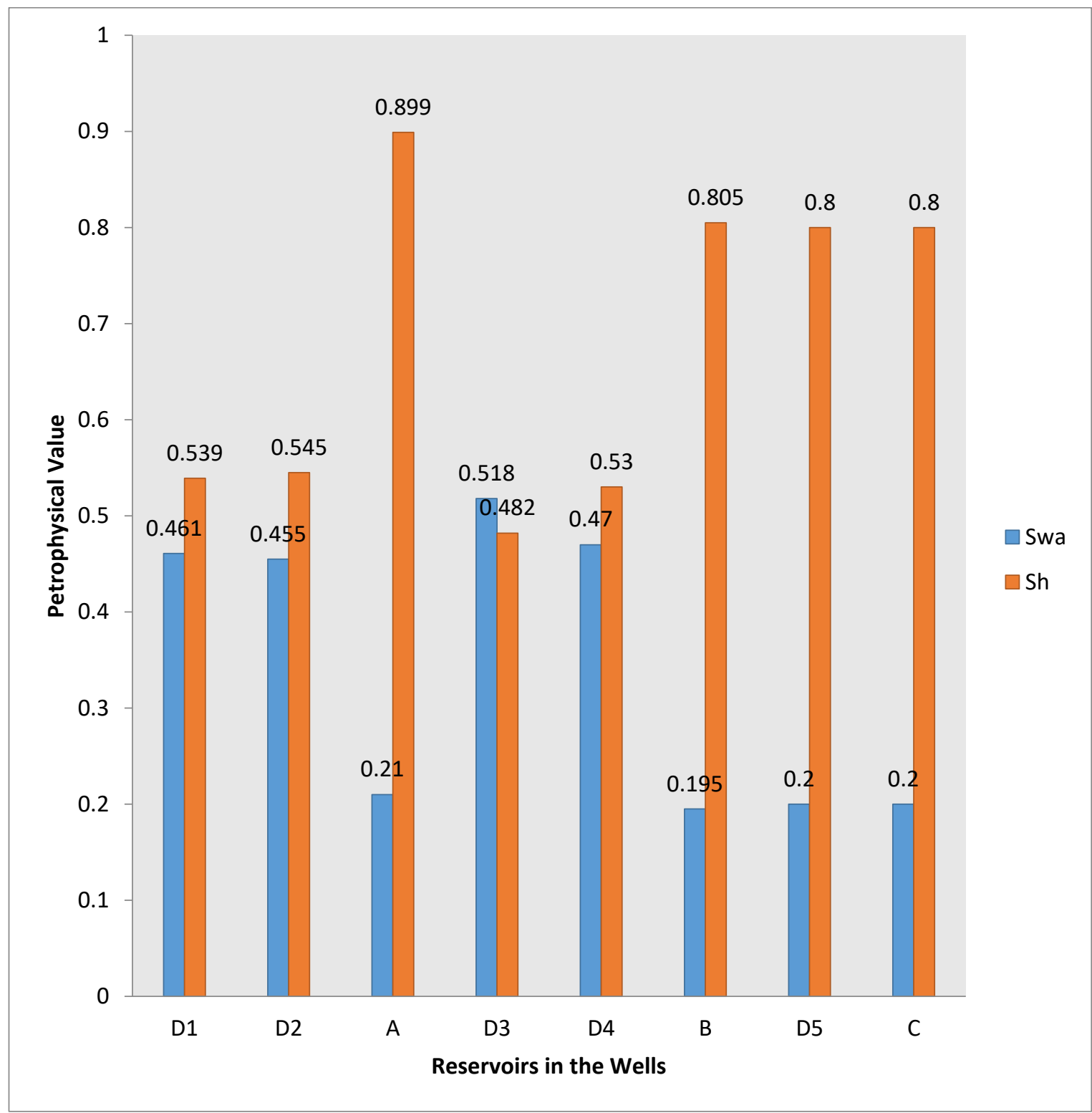

Fig. 15: Hydrocarbon Saturation Values.

From figure 15 the value of hydrocarbon saturation in the wells ranges from $80.0 \%-89.90 \%$ in reservoirs $\mathrm{A}, \mathrm{B}, \mathrm{C}$ in the wells. The hydrocarbon saturation estimated at the bypassed reservoirs D1, D2, D4, D5, range from $45.50-54.50 \%$. Reservoirs A and B have the highest gas saturation of $0.65 \mathrm{bbls} / \mathrm{scf}$ and oil saturation of $2.52 \mathrm{mbls}$ across the field. However production can go on in reservoirs C, D1, D2, D4, D5 in the wells at irreducible water saturation.

\section{Conclusion}

The seismic, well and core data were integrated in this research to predict reservoir performance and improve reservoir quality at mapped horizons. The models built is a pointer to environments of deposition in the field. The built model was also, used to characterized reservoirs in terms of geometry, porosity, permeable and nonpermeable rock units. The core, well data and the 3-D geological model produced were used to interprete the environment of deposition in the field.

\section{Acknowledgement}

The authors are thankful to the Director, Department of Petroleum Resources, Porth Harcourt, Nigeria for the provision of the data and the space to carry out this research.

\section{References}

[1] Amigun, J.O. (1998). Interpretation of seismic reflection data over Okpoko oil field, Niger Delta; (unpublished M.Sc thesis). Obafemi Awolowo University, Ile-Ife. 98P.

[2] Arche G.E (1942). The electrical resistivity log as aid in determining some reservoir characteristics Journal of Petroleum Technology, V.5, P. 54-622. https://doi.org/10.2118/942054-g.

[3] Asquith, G.B. and Krygowski, D. (2004). Basin well log analysis The Association of American Petroleum Geologist Bulletin. Tulsa Oklahoma, Vol.2, 44P.

[4] Azegbokhare, S.A and Abe, S.E (2010). Reservoir characterization of Usani well 1\& 2, offshore field Niger Delta Basin, using 3-D Seismic and well log data. Nigeria Journal of Applied Sciences, Vol. 28 , P.72-80.

[5] Beck, R.H. and Lehner, P. (1975). Oceans, new frontier in exploration. Association of American Petroleum Geologist Bulletin, Vol.69, P.253.

[6] Bush, D.A. (1975). Influence of growth fault on sedimentation and prospect evaluation. The Association of American Petroleum Geologist Bulletin, Vol.59, No.3, P.414-419.

[7] Burke, K. (1972). Long shore drift, submarine canyons and submarine fans in development of Niger Delta. Association of American Petroleum Geologist Bulletin, Vol.56, P.1975-1983.

[8] Cant, D.J. (1992). Subsurface facies analysis. Facies models: Response to sea level change. Geological Association of Canada. ISBN: 0919216498, P.409. 
[9] Doust, H. and Omatsola, M. E. (1990). Divergent passive margin basins. Association of American Petroleum Geologist Memoir 48, P. 201-238.

[10] Etu-Efeotor, J.O, (1997). Fundamentals of petroleum geology. Published by Paragraphics (an imprint of Jeson services). Port Harcourt, Nigeria. 146P.

[11] Evamy, D.D., Haremeboure, J. Kamierling, W.A. Knaap, W. A Molly and Rowland, P.H. (1978). Hydrocarbon Habitats of Tertiary Niger Delta, Association of American Petroleum Geologist Bulletin, Vol.62,P.1-39.

[12] Hamada, G.M. and AI- Awad, M.N.J., Petrophyical evaluation of low resistivity sandstone reservoirs. Journal of Canadian Petroleum Technology, Vol.39, No.7, P.7-14.

[13] Kehinde, D. O. and Ahzegbobor, P.A. (2015). Hydrocarbon trapping mechanism and petrophysical analysis of Afam Field, offshore Niger Delta Basin, Nigeria. International Journal of Physical Sciences, Vol.10, P. 222-238. https://doi.org/10.5897/IJPS2015.4275.

[14] Lambert-Alkhionbare, D.O. (1981). The Agbada shales as source rocks for the Niger Delta Petroleum. Abstract of proceedings $10^{\text {th }}$ Annual Conference. Nigerian Mining and Geoscience Society, Lagos.P.180- 202.

[15] Mogbolu, P. (2010). Identification and quantification of thiny bedded low resistivity pay zone in Niger Delta (Society of Petroleum Engineers Annual Technical Conference and Exhibition 19-22), Florence Italy, ISBN 978-1-55563-300-4), P.1-8.

[16] Roy, W. (1997). The accurancy of well ties: Practical procedures and examples. Society of Exploration Geophysicist expanded Abstract 16, P. 816. http://dx.doi.org/101190/1.886137.

[17] Schlumberger (2013). Log interpretation principles/application/charts. Exploration and Production (E \& P) Technical Journal of Middle East, Vol.9, P.1-140.

[18] Sheriff R. and Geldart L. (1999). Exploratory seismology. Cambridge University Press, London.

[19] Short, K.C. and Stauble, A.J. (1967). Outline of geology of NigerDelta. Association of American Petroleum Geologist Bulletin, Vol. 51, P.761-779.

[20] Swanson, D.C., (1979). Swanson, D.C. (1979). Deltaic deposits in the pennsylvannian upper Morrow Formation of the Anadarko basin, in N.J. Hyne, edition, Pennsylvannian sandstone of the mid-continent: Tulsa Geologic Society Publication No.1, P.115-168.

[21] Weber, K.J. and Daukoru, E.M. (1975). Petroleum geology of Niger Delta. $9^{\text {th }}$ World Petroleum Congress, Vol.2, P.209-221.

[22] Wyllie, M.R.J, Gregory, A.R. and Gardner, G.H.F. (1958). An experimental investigation of factors affecting elastic wave velocities in porous media. Geophysics, Vol. 23, No.3, P. 89-121. https://doi.org/10.1190/1.1438493. 